\title{
COMPOSTING SUGAR CANE BAGASSE AT FULL SCALE: ORGANIC MATTER DECAY KINETICS, METAGENOMICS AND PLANT-GROWTH PROMOTING BACTERIA CAPABILITIES
}

Compostaje de bagazo de caña de azúcar a escala comercial: cinética de decaimiento de materia orgánica, metagenómica y capacidades bacterianas para la promoción del crecimiento de plantas

\author{
Jesús Bernardino VELÁZQUEZ FERNÁNDEZ ${ }^{1 *}$, Irma Paz HERNÁNDEZ-ROSALES ${ }^{2}$ and \\ Silvia Maribel CONTRERAS RAMOS ${ }^{1}$
}

${ }^{1}$ Centro de Investigación y Asistencia en Tecnología y Diseño del Estado de Jalisco A.C. Avenida Normalistas 800, CP 44270, Guadalajara, Jalisco, México

${ }^{2}$ Unidad Académica de Ciencias Básicas e Ingenierías, Universidad Autónoma de Nayarit. Ciudad de la Cultura Amado Nervo, CP63155, Tepic, Nayarit, México

*Corresponding author: jesusbvf@gmail.com

(Received: January 2019; accepted: September 2019)

Key words: compost, biodegradability, microbiome, biofertilizer

\begin{abstract}
The management difficulties implied at field-scale composting make difficult to perform kinetic studies, leading to a gap in the literature at real enterprise conditions. Although composting has been reported to show a three-phase kinetics regarding the temperature, for organic matter, an exponential decay kinetics has been described. Organic matter decay, internal temperature of sugar-cane bagasse compost windrows along the time at enterprise (field-scale) level and the microbial community of the final product were analyzed. Final compost was achieved at 12-17 weeks with 41-47\% humidity and 31$47 \%$ organic matter content. Kinetics model of organic matter biodegradation showed $\mathrm{R}^{2} \geq 0.6$ and no differences between exponential or linear model $\mathrm{R}^{2}$ were observed. Linear biodegradation constant was $2.5 \%$ of organic matter loss/week, ranging from 2.2 to $3.7 \%$ week. The most abundant bacterial classes were Bacilli and Anaerolineae from metagenomic analysis. Bacterial cultures isolated showed plant-growth promoting and aromatic degradation capabilities. This shed light to future prospection studies on real-world composting for enterprises and scientists.
\end{abstract}

Palabras clave: composta, biodegradabilidad, microbioma, biofertilizante

\section{RESUMEN}

Las dificultades de manejo del compostaje a escala comercial o de campo dificultan el desarrollo de estudios cinéticos, lo que ha llevado a una ausencia de información en la literatura en las condiciones reales comerciales. Aunque se ha reportado que el compostaje tiene tres fases según la temperatura y la materia orgánica, se ha descrito que sigue una cinética de decaimiento exponencial. En el presente trabajo se analizaron la disminunición de materia orgánica y la temperatura interna y externa de filas de composta de bagazo de caña a lo largo del tiempo a nivel comercial (escala de campo) y 
metagenómica del producto final. La composta final se alcanzó a las 12-17 semanas con 41-47 \% de humedad y 31-47 \% de materia orgánica. El modelo cinético de degradación mostró una $\mathrm{R}^{2} \geq 0.6$ y no se observaron diferencias entre el ajuste al modelo exponencial y el lineal. La constante de degradación lineal fue de $2.5 \%$ materia orgánica/ semana, en un rango entre 2.2 y $3.7 \%$ /semana. Las clases bacterianas más abundantes de los análisis metagenómicos del producto final fueron Bacilli y Anaerolineae. Los aislados bacterianos cultivados mostraron capacidad de promoción de crecimiento de plantas y degradación de aromáticos. Esto aporta conocimiento para futuros estudios de prospección para cientìficos y empresas que realicen compostaje a nivel comercial.

\section{INTRODUCTION}

Sugarcane bagasse is the agricultural waste generated in the largest amount for sugar production in Latin America. Because composting makes possible to biodegrade organic matter like bagasse, manure and other waste, the United States Environmental Protection Agency (USEPA) has recommended its use for contaminant biodegradation (EPA 1998, EPA 2016). The final product, the compost, can be used as a fertilizer and to bioremediate soil, air and water, or to control soil erosion (EPA 1997a, EPA 1997b, 2006).

Three temperature phases have been described during composting (EPA 1998, Xu and Li 2017). The first phase consists of an increase of temperature up to $50^{\circ} \mathrm{C}$ or higher. Once reached the higher temperature, the second phase or thermophilic begins as long as those temperatures are kept. The third phase consists of a decrease of the temperature as the compost reaches its maturity.

The increase and hold at high temperature $\left(50{ }^{\circ} \mathrm{C}\right.$ and higher) during the first and second phases is caused by the metabolic activity of the microbiota, which uses the organic matter as energy source and would help kill pathogens (EPA 2016). Thus, heterotrophic microorganisms are the majority in this phase.

As the organic matter decreases (EPA 1998), the percentage of biodegradable organic matter depends on the input material. Biodegradable content is $60-90 \%$ in normal waste. When the waste is contaminated with organic compounds, that percentage might vary. For instance, agave bagasse could be around $88 \%$ (Rodríguez et al. 2013), for biosolid wastes $70 \%$, and for leguminous or rumen residues, $80-85 \%$ has been reported (Arango-Osorno et al. 2016). The final compost commonly has 30-50\% of organic matter (EPA 1998, Rodriguez et al. 2013, Arango-Osorno et al. 2016).

The time needed to reach the mature compost is highly variable. Normally, it takes 8 to 26 weeks (EPA
1998, Arango-Osorno et al. 2016, Xu 2018). Such broad range is due to the variability in environmental conditions, management of organic matter, starting microbiota, and even the scale: laboratory, pilot or field scale have shown different results and times for composting (EPA 1998).

At laboratory scale, usually starts with 1 ton or less of input material, most cases work at $\mathrm{kg}$ scale, and in reactors with hundreds of $\mathrm{kg}$. At pilot scale, composting is usually carried out at facilities or open sky. Feedstock is disposed in piles and the amount is at higher level of magnitude: tenths or hundreds of tons, approximately 10 to 20 cubic meters (EPA 1998). At field scale or full level (commercial) in Latin America, normally, composting is at open sky in fields disposed for that purpose and material to be composted is distributed in several windrows, which are large rows of piles. Each windrow involves several hundreds or thousands of tons of starting material, depending of the length of the windrow, but the windrow/pile width could be similar to that in pilot scale (approx. 2-3 m, which allows similar aeration). Because of the large size, pile management is difficult at pilot scale, so in order to keep humidity, also large equipment is required. In other words, the management could be different from those at lower scales and the temperature and humidity could not be controlled similarly. Also, there is another remarkable difference between pilot and full scale: an entire windrow is not deposited at the same time (day, for instance), i.e., it is formed as the feedstock is brought to the field at a variable rate. Keeping this in mind, when the compost is mixed, it could be scrambled with an adjacent pile (within the same windrow) which could have been deposited 1-3 days before or after. Thus, it is logic to think that it will be a large variability in physical and chemical parameters. Consequently, the microbiota composition and metabolism in field scale composting could be altered, and the composting phases (according to temperature or organic matter decay) may not be as expected for smaller scales. 
This is why, scarce literature exists on composting at field/commercial level in Latin America.

The organic matter decay has been described to follow an exponential or first order kinetics (EPA 1998) implying that the first phase has a larger degradation rate than the second one. Although, some authors suggest that it could be linear or even follow other mathematical models, as reported in laboratory scale (Roncevic et al. 2005). As far as we know, no report is found about the kinetics of organic matter decay at a field scale and the possible biological implications of the final microbiota product. The present work aims to investigate what model fits best for degradation kinetics in open field composting, and to study the microbiota composition, its plant growth promoting, and degradation properties of the final compost.

\section{MATERIAL AND METHODS}

The work was carried out at field-scale from bagasse waste on an open field $\left(21^{\circ} 3\right.$ " $38.5^{\prime \prime} \mathrm{N}$ $104^{\circ} 53^{\prime} 8.0^{\prime}$ 'W, 1040 masl, temperatures between 19 and $34{ }^{\circ} \mathrm{C}$ along the year). The bagasse waste was mixed with other waste of sugar cane processing to obtain sugar, but the bagasse constitutes at least $80 \%$ of the feedstock (initial organic carbon ranged from 29 to $84 \%$ and humidity from 49 to $64 \%$ ) and the rest $20 \%$ is cane-sugar ash. The rows have $3 \mathrm{~m}$ width and a starting height of $2 \mathrm{~m}$, thus, at the beginning every pile has around a hundred tons approximately. As the material was being deposited a pile after another, a windrow of $100 \mathrm{~m}$ long ( $3 \mathrm{~m}$ width approx.) is formed after 3-5 days (10-15 piles). Subsequent windrows were deposited $3 \mathrm{~m}$ away from the previous one, so the equipment for mixing could enter between rows properly (Fig. 1). At the end, ten windrows were deposited in the field. Because the production of the feedstock is not perfectly constant, entire windrows were deposited at different intervals (Table I).

As the starting material is humid, during the first four weeks of composting, no extra water is added to the composting piles. Nevertheless, pile mixing was carried out by mechanic inversion once a week during the composting. During mixing, around 800-1000 L of water/ton were added to keep the compost humid.

\section{Sampling}

Sampling and analysis were similar to that described by Rodríguez et al. (2013). Each other windrow was selected to sample, thus, only five
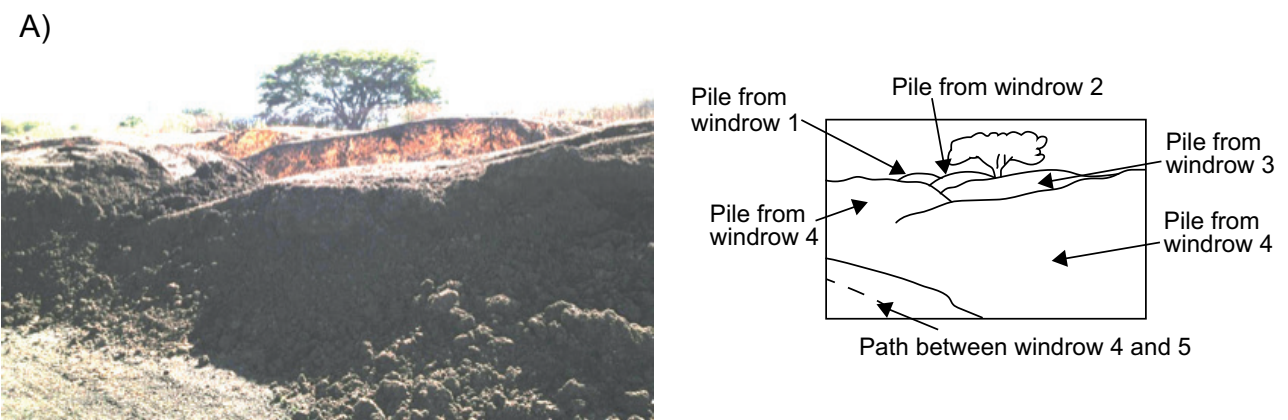

B)
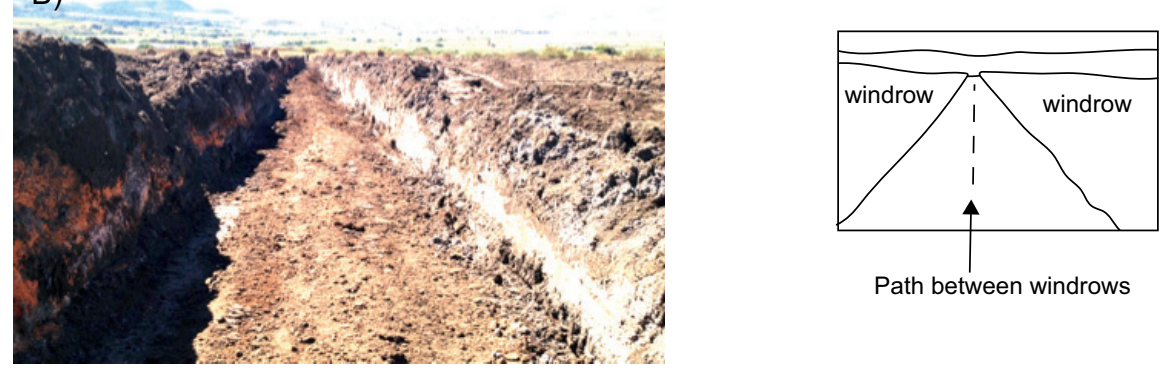

Fig. 1. Picture (left) and scheme (right) of two compost windrows. A) Longitudinal view. Five piles from four different windrows. Piles from windrows 2 and 3 were behind the freshly disposed windrow (4) and show an orange coloration by fungi. B) Cross-sectional view from a row between two windrows. The right windrow was more recently deposited than the left one. Orange color in the left windrow is due to fungi 
TABLE I. TIME AND CONDITIONS OF COMPOSTING AT FIELD-SCALE

\begin{tabular}{|c|c|c|c|c|c|}
\hline & \multicolumn{5}{|c|}{ Site/windrow } \\
\hline & 1 & 2 & 3 & 4 & 5 \\
\hline \multicolumn{6}{|l|}{ Time at which that windrow } \\
\hline was started (days, from day 0$)^{\mathrm{a}}$ & 0 & 12 & 22 & 35 & 50 \\
\hline Maturation time (days) & 120 & 122 & 112 & 85 & - \\
\hline Organic matter at start (\%) & 74 & 75 & 72 & 81 & 84 \\
\hline Organic matter at the end (\%) & 43 & 31 & 47 & 36 & 45 \\
\hline Humidity at start (\%) & 61 & 64 & 64 & 69 & 73 \\
\hline Humidity at the end $(\%)^{d}$ & 41 & 45 & 47 & 41 & 47 \\
\hline Number of samplings & 5 & 6 & 7 & 6 & 3 \\
\hline Biodegradation constant & -0.312 & -0.403 & -0.349 & -0.527 & nd \\
\hline
\end{tabular}

${ }^{\text {a It }}$ refers at the number of days passed after the first windrow was completed, nd $=$ not determined.

windrows were sampled at three points: two next to the edges and one in the middle. Approximately $1 \mathrm{~kg}$ sample was taken at $20 \mathrm{~cm}$ depth. The three samples from the same windrow were mixed and labeled. Sampling was approximately every 6-8 days. Every time a sample was taken, outer and inner temperature was measured: outer temperature was measured by placing a mercury thermometer on the windrow and the inner temperature by using a thermocouple probe omega HH100 $1 \mathrm{~m}$ inside the pile at the sampling point.

Sometimes, mixing or sampling was suspended because occasional rains, so the time interval for sampling was not homogeneous. Time zero was considered after the windrows were entirely deposited (so the first pile of that windrow could have been deposited 5 days or less before time zero).

Organic matter and humidity were determined according with NOM-021-RECNAT-2000 (SEMARNAT 2000). Samples were dried at $40{ }^{\circ} \mathrm{C}$ to constant weight before analysis. Every analysis was carried out six times and only the mean is reported.

\section{Bacterial community analysis}

Compost DNA was obtained by following procedure of MPBio FastDNA Spin kit for Soil ${ }^{\circledR}$ on compost samples when no significant change in organic matter content was observed for two weeks, when maturity is considered to be reached. Metagenomic analysis was performed by NGS service at CIADMazatlan (www.ciadmazatlan.com) service by using Illumina ${ }^{\circledR}$ NGS miniSeq The methodology used was an analysis of the microbiota by massive sequencing of the $16 \mathrm{~S}$ ribosomal gene with the primers $\mathrm{V} 3-338 \mathrm{f}$ and V3-533r with Illumina adapters to amplify the V3 region only. Finally, the samples were sequenced on the Miniseq device of Illumina in standard conditions (300 cycles, 2X150). The $16 \mathrm{~S}$ ribosomal RNA sequences obtained were verified for the quality, chimeras were eliminated, after pairing and singleton elimination, paired sequences were searched against SILVA high quality ribosomal RNA databases http:// www.arb-silva.de. Subsequently, species with less than $1 \%$ were grouped as "others" to have a clear view of the dominant bacteria species.

Culturable bacteria were isolated by plating $50 \mu \mathrm{L}$ of a compost suspension $(1 \mathrm{~g} / 10 \mathrm{~mL}$ of sterile saline solution) on soy trypticasein agar. Twenty colonies were randomly taken and cultured in Luria-Bertani broth overnight previous to measure plant-growth promoting and $\mathrm{C} 23 \mathrm{O}$ enzyme activities. Species from sixteen isolates were identified by using MALDITOF of Bruker ${ }^{\circledR}$.

Phosphate solubilization was measured after placing $100 \mu \mathrm{L}$ of overnight culture in $8 \mathrm{~mL}$ of phosphorite Pikovskaya broth $(5.0 \mathrm{~g} / \mathrm{L}$ phosphorite, $4 \mathrm{mg} / \mathrm{L}$ manganese sulfate, $2 \mathrm{mg} / \mathrm{L}$ ferrous sulfate, $0.2 \mathrm{~g} / \mathrm{L}$ sodium chloride, $0.2 \mathrm{~g} / \mathrm{L}$ potassium chloride, $0.5 \mathrm{~g} / \mathrm{L}$ yeast extract, $0.3 \mathrm{~g} / \mathrm{L}$ magnesium sulfate, $0.5 \mathrm{~g} / \mathrm{L}$ ammonium sulfate, $10 \mathrm{~g} / \mathrm{L}$ glucose). After $48 \mathrm{~h}$ incubation at $28^{\circ} \mathrm{C}$, phosphate concentration in supernatant was measured by using Hanna kits. No inoculum was used as a control. Analysis were made by triplicate.

Indolacetic acid (IAA) production was evaluated by Salkowski reaction. Tubes containing $800 \mu \mathrm{L}$ of tryptone culture medium $(5 \mathrm{~g} / \mathrm{L}$ glucose, $1 \mathrm{~g} / \mathrm{L}$ dibasic potassium phosphate, $0.4 \mathrm{~g} / \mathrm{L}$ ammonium nitrate, $0.2 \mathrm{~g} / \mathrm{L}$ sodium chloride, $0.4 \mathrm{~g} / \mathrm{L}$ magnesium sulfate, $20 \mathrm{~g} / \mathrm{L}$ tryptone) with or without $0.1 \mathrm{~g} / \mathrm{L}$ tryptophan (intermediate for IAA production) were inoculated with $10 \mu \mathrm{L}$ of overnight culture. After $48 \mathrm{~h}$ incuba- 
tion at $28{ }^{\circ} \mathrm{C}$, cell pellets were resuspended with Salkowsky reagent $(1 \mathrm{~mL} 0.5 \mathrm{M}$ ferric chloride, 50 $\mathrm{mL}$ water and $30 \mathrm{~mL}$ concentrated sulfuric acid). Tubes were incubated at room temperature for 30 min. Absorbance was measured at $530 \mathrm{~nm}$. Concentration was calculated by interpolation within a calibration curve by IAA. Analyses were made by triplicate.

Siderophore production was determined by chromeazurol $\mathrm{S}$ reaction with ferric ion in agar plates. Siderophore reaction agar was prepared by adding $10 \mathrm{~mL}$ of solution $1(0.1 \mathrm{mM}$ ferric chloride, $0.6 \mathrm{mg} / \mathrm{mL}$ chromeazurol $\mathrm{S}, 0.728 \mathrm{mg} / \mathrm{mL}$ hexadecyltrimethylammonium bromide) to a mixture of $800 \mathrm{~mL}$ of solution 2 (37.8 g/L PIPES, $0.375 \mathrm{~g} / \mathrm{L}$ monobasic potassium phosphate, $0.625 \mathrm{~g} / \mathrm{L}$ sodium chloride, $1.25 \mathrm{~g} / \mathrm{L}$ ammonium chloride, $2 \%$ agar $\mathrm{pH} 6.8$ ) with $70 \mathrm{~mL}$ of solution 3 (2.9\% glucose, $2.9 \%$ mannitol, $0.7 \%$ magnesium sulfate, $0.016 \%$ calcium chloride, $0.0017 \%$ manganese sulfate, $0.002 \%$ boric acid, $0.00006 \%$ cupric sulfate, $0.0017 \%$ zinc sulfate, $0.0014 \%$ sodium molybdate). After autoclaving, siderophore reaction agar was poured on Petri dishes: A color change to orange (from blue) indicates siderophore production. The diameter of the halo is an indirect measurement of the amount of produced siderophores. Analyses were made by triplicate.

For $\mathrm{C} 23 \mathrm{O}$ enzyme activity measurement, overnight cultures were resuspended in Davis minimum medium and incubated $24 \mathrm{~h}$ at $28^{\circ} \mathrm{C}$. Bacterial pellets were resuspended in $1 \mathrm{~mL}$ of $40 \mathrm{mM}$ phosphate buffer ( $\mathrm{pH}$ 7.5). Enzyme activity was measured spectrophotometrically by adding $50 \mu \mathrm{L}$ of cell suspension on 1 $\mathrm{mL}$ of $40 \mathrm{mM}$ phosphate buffer containing $2.5 \mathrm{mM}$ catechol. Molar absorptivity of the product $36000 / \mathrm{M} /$ $\mathrm{cm}$ was used (Hupert-Kocurek et al. 2012). Activity was reported by $\mu$ moles of products $/ \mathrm{min} / \mathrm{mg}$ protein. Total protein was determined by Lowry method (Ramírez-Sandoval and Velázquez-Fernández 2013). Analyses were made by triplicate.

Models and descriptive statistical analysis were carried out with Matlab R2017a.

\section{RESULTS AND DISCUSSION}

The timing needed for pile production at field scale provokes that every windrow is generated at different times (Table I). In the present work, the windrow at site 5 was formed ca 50 days after the first windrow. Thus, every windrow was formed approximately every 5-7 days, since the site 5 corresponds to the tenth windrow. Sampling was done weekly, but not every site could be sampled every time due to the difficulty of access when piles were being mixed. As a result, each site was sampled only 5-7 times, except for the site 5 (the last formed), which was sampled only 3 times. At the end, mature compost piles were $1 \mathrm{~m}$ height, and texture was similar to humus. It took 4 to 5 months to reach that point, so the longest time reported was around 120 days or more (Table I). It took 85 to 122 days, i.e., 12 to 17 weeks to reach mature compost (according to the absence of organic matter variation). This is similar to the time from a pilot-scale study with agave bagasse, previously reported by Rodríguez et al. (2013). This is interesting, since we could reach similar maturation times, regardless of the feedstock. Also, this time is within the interval suggested by EPA (1998) for composting: 8 to 26 weeks, i.e., 56 to 182 days. In contrast, at laboratory scale, maturation could be reached in 60 days (8-9 weeks, Arango-Osorno et al. 2016). Keeping this in mind, it suggests that the scale is even more important to be taken into account for time planning that the feedstock per se.

The humidity at the beginning (after the windrow was entirely formed) ranges from 61 to $73 \%$, while at the end was $41-47 \%$ (Table I). Although the initial values are different from other studies due to the feedstock, final values are close to those reported in literature. For instance, Rodríguez et al. (2013) found final humidity of 50-60\% at pilotscale, while Arango-Osorno et al. (2016) reported values of $30-40 \%$ at laboratory scale. A value of $40 \%$ of humidity is considered the minimum to sustain the microbial activity for biodegradation, but values over $70 \%$ could avoid proper aeration, inhibiting microbial growth and activity (Bueno-Márquez et al. 2008). Because the initial values were over $61 \%$, no water was added to the composting windrows for the first four weeks. The concomitant high values of organic matter allowed fungi growth on the piles during the first month (Fig. 1). The growing fungus confers a white/orange color at the exterior of the pile, which is not observable when sampling the core of the pile. Despite that, using conventional microbiological methods, those fungi can be grown in the laboratory, but the microbial biodiversity is too high in richness, and abundance (data not shown). Since it was not the aim of this work, the microbial biodiversity is currently under study and will be published in the future.

\section{Changes in temperature}

Although the three thermal phases are to be expected during the composting: rising, thermophilic 
and lowering (EPA 1998), several works have reported no significant changes at laboratory or pilot scales. For instance, at laboratory scale, Arango-Osorno et al. (2016) did not observe changes during the entire process, i.e., the temperature was in the mesophilic range during the entire composting process $\left(20-30{ }^{\circ} \mathrm{C}\right)$. Contrastingly, at pilot scale, Rodríguez et al. (2013) found a higher temperature $\left(45-70{ }^{\circ} \mathrm{C}\right)$, but with no significant changes during the whole process. Similarly, in the present work, temperature ranged from 40 to $70{ }^{\circ} \mathrm{C}$, exception made of site 2 at 94 days, which was lower since it had been turned and watered just before sampling (Fig. 2). Thus, for sampling, no other windrow was sampled if it had been turned and watered in the same day or the previous to the sampling. This also suggests that the turning
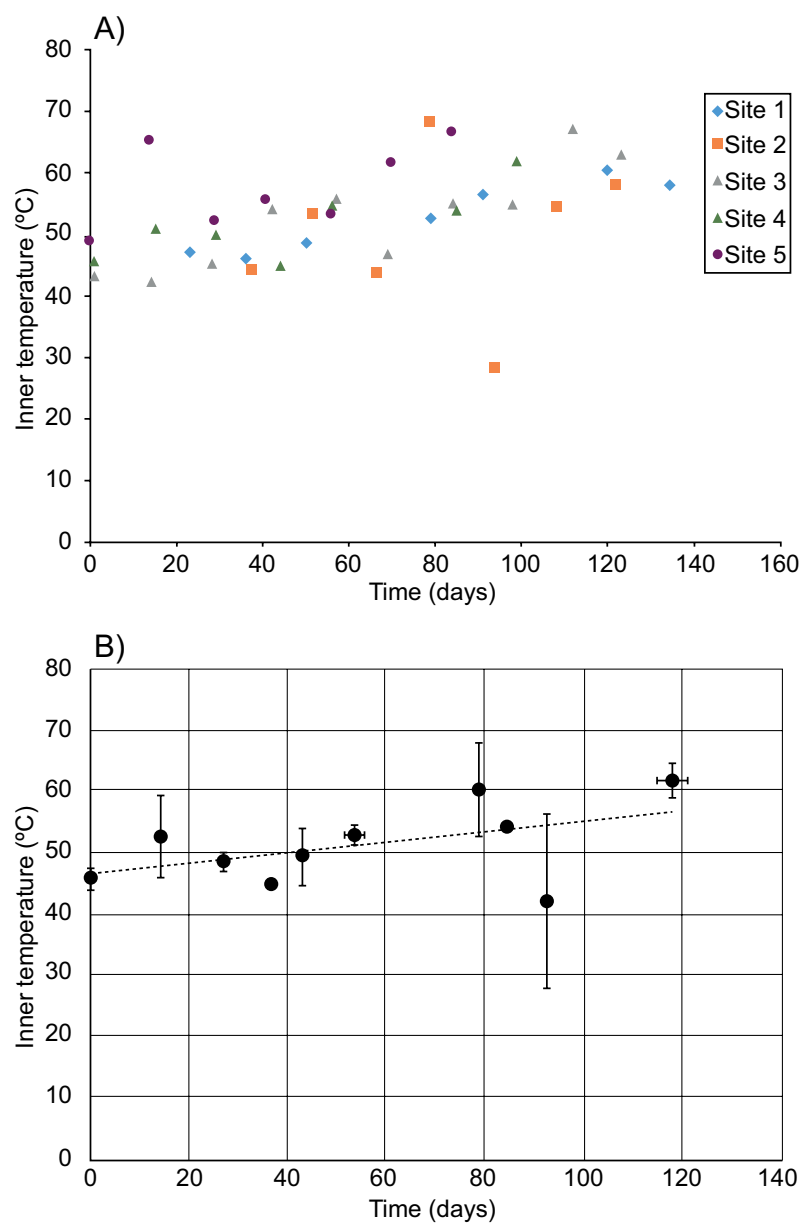

Fig. 2. Inner temperature changes during cane bagasse composting at field scale. A) Values from each sampling site. B) Average values grouped within a week window. (Mean \pm standard deviation is shown). Dotted line represents the minimum square linear regression and water addition lower the compost temperature by $20^{\circ} \mathrm{C}$. No rising phase could be detected, so, the temperature increases within the first five days, i.e., the time that takes to complete the pile.

The differences between the temperature ranges at laboratory scale and pilot or field scales could be explained in terms of the windrow/pile depth and surface. At laboratory scale, compost piles have generally no more than $0.5 \mathrm{~m}$ depth, while at pilot scale they are $1 \mathrm{~m}$ or even deeper. The depth at laboratory scale allows better pile aeration and heat exchange, since most laboratory compost containers have no more than $20 \mathrm{~cm}$ distance between the core and the surface. At field scales, we measured external temperature by placing a mercury thermometer on the surface of the pile, and when it was introduced $20 \mathrm{~cm}$ within the pile, the difference was negligible or less than $2{ }^{\circ} \mathrm{C}$. This finding and the behavior of humidity and organic matter suggest that pilot scale is closer to field scale composting than laboratory scale, regardless of the feedstock. As can be observed in figure 3, external temperature ranged from 20 to $35^{\circ} \mathrm{C}$, which is similar to those values observed at laboratory scale (Arango-Osorno et al. 2016).

Inner and external temperatures had a low determination coefficient vs. time: $\mathrm{R}^{2}=0.50$ and 0.52 , respectively. Positive slope values reflect a temperature increase rate of $0.59^{\circ} \mathrm{C} /$ week and $0.24{ }^{\circ} \mathrm{C} /$ week (Figs. 2 and $\mathbf{3}$ ). Therefore, temperature variations are larger than any observed correlation or rate, in other words, there is no significant correlation between time and inner or external temperature (or their difference). As the depth could affect inner temperature and aeration, it is logic to assume that it would also affect biodegradation of organic matter.

\section{Organic matter kinetics}

Regardless of the scale, compost organic matter levels, at the end of composting process are expected to be $30-50 \%$. Organic matter decay and maturation time was similar (Table I) among the five studied piles and with the values reported for pilot scale (Fig. 4; Rodríguez et al. 2013). Three mathematical equations were evaluated to model organic matter decay, as it has been described previously by Roncevic et al. (2005): one linear and two exponentials, corresponding to the following:

$M=M_{0}-k t$

$M=M_{0} e^{-k t}$ 


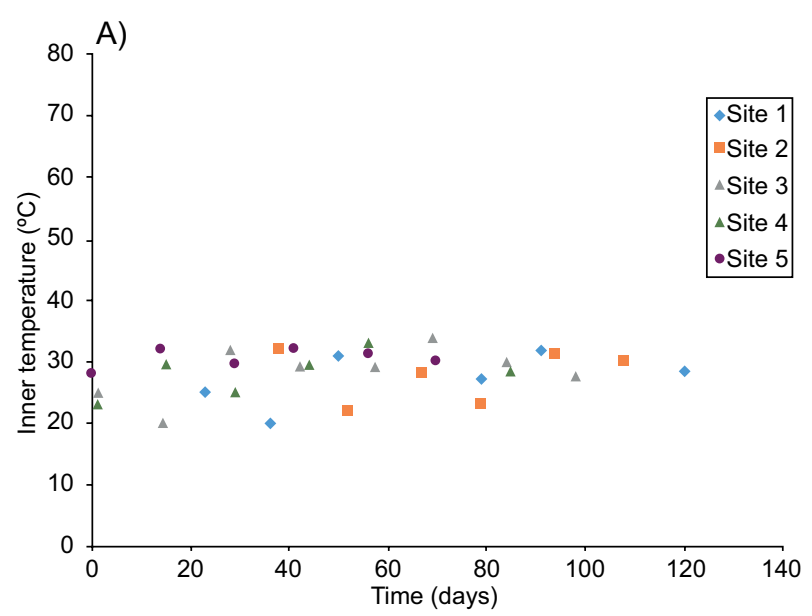

B)

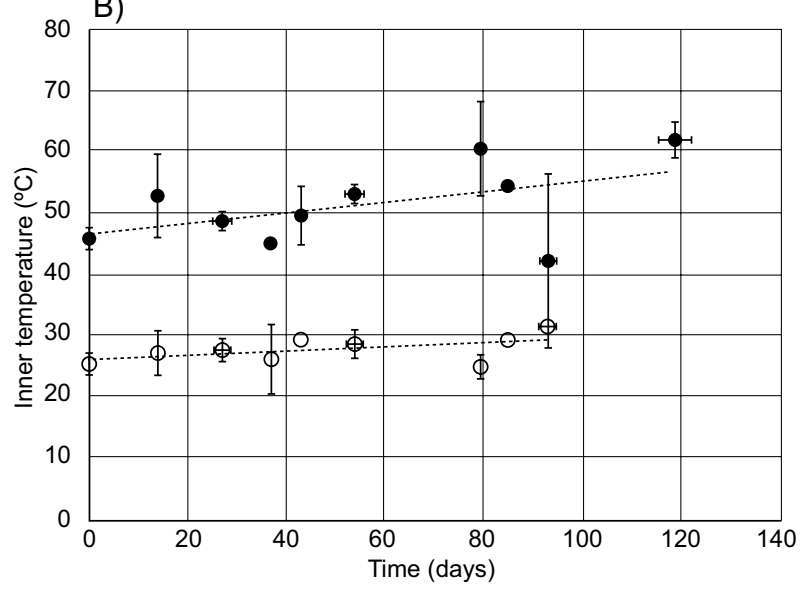

Fig. 3. External temperature change during cane bagasse composting at field-scale. A) Values from each sampling site. B) Open circles: average values (grouped within a week window). For comparison, corresponding average values of inner temperature (closed circles, same as in Fig. 2) are shown. In both cases, mean \pm standard deviation values are shown. Dotted line represents the minimum square linear regression

$M=M_{0} e^{-k \sqrt{t}}$

Where $M$ represents organic matter content in percent (dry basis) at time t; $M_{0}$, calculated initial organic matter (or at time 0 ) in percent; $t$, time in days and $k$, decay or degradation rate constant according to the respective model, in 1 / days only for linear and first exponential model (equations 1 and 2).

For comparison, averages or all the values (Fig. 4A) were used to evaluate the correlation (Table II). Average values were also used for contrast (Fig. 4B). They were calculated considering the corresponding time zero for each site regardless the site, in other words, values from different sites were averaged when they were within a time window of two days.

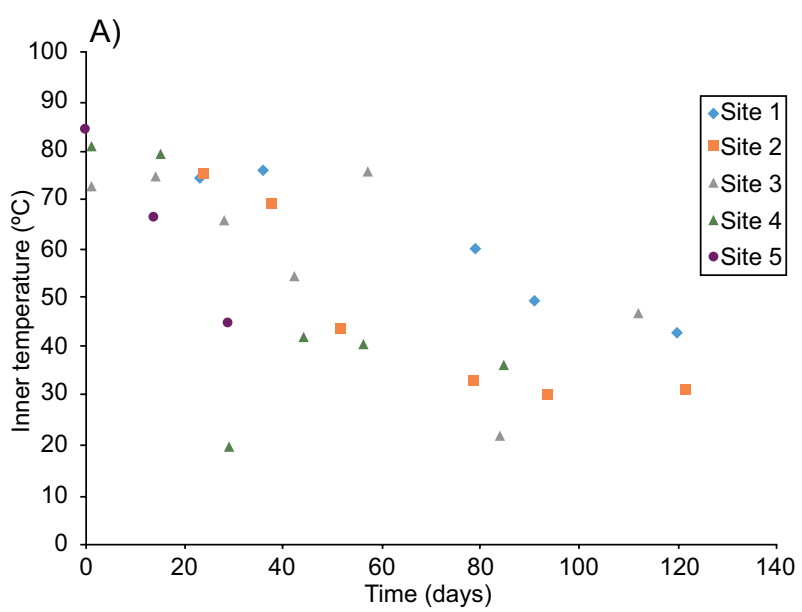

B)

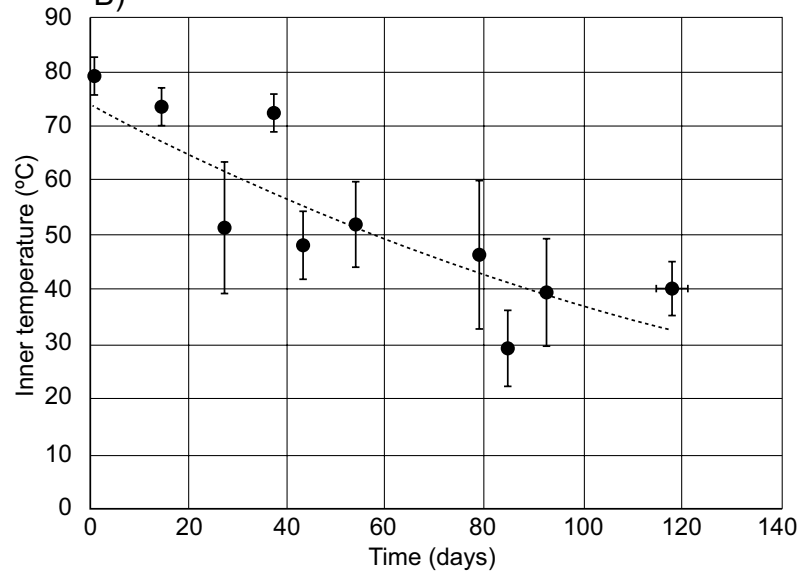

Fig. 4. Variation of organic matter content during cane bagasse composting at field-scale. A) Values from each sampling site. B) Average values (grouped within a week window). Dotted line represents exponential regression

TABLE II. KINETIC PARAMETERS FOR ORGANIC MATTER DECAY

\begin{tabular}{cccc}
\hline Model & \multicolumn{1}{c}{$\mathrm{R}^{2}$} & $\mathrm{M}_{0}$ & $\mathrm{k}^{\mathrm{a}}$ \\
\hline \multicolumn{4}{l}{ Using all data $(\mathrm{n}=28)$} \\
\hline-0.665 & 72.1 & -0.348 \\
-0.593 & 70.5 & -0.006 \\
-0.629 & 70.5 & -0.083 \\
\hline \multicolumn{4}{l}{ Average values ( $\mathrm{n}=10)$} \\
\hline & -0.834 & 73.3 & -0.366 \\
& -0.822 & 74.3 & -0.007 \\
-0.833 & 91.7 & -0.086 \\
\hline
\end{tabular}

For first and second models, units of $\mathrm{k}$ are 1 /days

$\mathrm{R}^{2}=$ determination coefficient, the other variable depends on the equation as listed in the first column. $\mathrm{M}_{0}=$ organic matter at time $0, \mathrm{k}=$ kinetics constant 
Correlation coefficients are close or higher than 0.6 , regardless of the averaging or the model. Considering that they arise from field-scale measurements having several variables that were not controlled, they reflect proper models. The use of average values led to higher correlation coefficient values (Table II). Although averaging reduces the number of time points for modeling, $(\mathrm{n}=10)$, the $\mathrm{n}$ is still above 7 , below which the $\mathrm{n}$ could have an important effect on the coefficient correlation. The values of correlation coefficient from the three models are very similar. Regardless of the $n$ or model used, $M_{0}$ value is $70-74 \%$, exception made of the third model described by Roncevic et al. (2005) for hydrocarbon degradation. Using that model, $M_{0}$ is higher than the rest of all the models. Although the $M_{0}$ value was calculated for the models, the values are very close to the real ones, which were $72-84 \%$. Thus, the third model using seems not to be adequate or advantageous. Moreover, $\mathrm{R}^{2}$ and $M_{0}$ values from the linear and exponential models are similar, suggesting that either model could be used. This can be observed graphically: when plotting the calculated values of organic matter from the exponential model within the time window of the present work, they look quite linear (Fig. 4B).

The linear model is easier and more pragmatic to use in field, thus, quick calculations can be done. Also, the kinetic constant $k$ is very similar regardless the number of data points used, raw or average values, suggesting that even the data variability from this field-scale study does not impact on the kinetic parameters. Taking all this into account, it is possible to model the degradation kinetics of the organic matter decay at field-scale using a linear model, which will ease on-field calculations. Parameter $k$ values for each site (Table III) range from -0.31 to $-0.53 \% /$ day, i.e., 2.2-3.7\% of organic matter is degraded per week. As far as we know, no other kinetic constants of organic matter decay at field-scale have been reported. Knowing the kinetic model and constants or organic matter decay will help prospect or predict compost degradation at the commercial level and ease the (on-field) calculations, which in its turn, will reduce the effort and time the analysis needs to be performed on the field. The fact that the data adjusts to a linear model seems to be due to a pseudo-zero order. Although seems independent of the organic carbon content, that could be caused by the slow process and high variability of the parameters involved such as temperature or other metabolic needs for bacterial biodegradation.

\section{Bacterial community in compost}

The most abundant bacterial classes are Bacilli (5.6\%) and Anaerolineae (9.2\%, Fig. 5). Bacilli group contains heterotrophic bacteria. Recently, a species of Bacillus has been found to be termophillic and encode for a mannannase, a hemicellulase

TABLE III. PLANT-GROWTH PROMOTING CAPABILITIES AND CATECHOL 2,3-DIOXYGENASE (C23DO) ACTIVITIES.

\begin{tabular}{|c|c|c|c|c|c|}
\hline \multirow[t]{2}{*}{ Bacterial genus } & \multirow{2}{*}{$\begin{array}{l}\text { Phosphate } \\
\text { (mg/L) }\end{array}$} & \multicolumn{2}{|c|}{ Indolacetic acid production $(\mu \mathrm{g} / \mathrm{mL})$} & \multirow{2}{*}{$\begin{array}{l}\text { Siderophore } \\
\text { production }\end{array}$} & \multirow{2}{*}{$\begin{array}{l}\text { C23DO } \\
\text { activity }\end{array}$} \\
\hline & & with Trp & without Trp & & \\
\hline Bacillus & 6.8 & - & - & - & 0 \\
\hline Bacillus & 5.9 & 52.7 & - & - & 10.2 \\
\hline Bacillus & 4.8 & 8.8 & 3.0 & - & 0 \\
\hline Bacillus & 7.3 & - & - & - & 0 \\
\hline Bacillus & 5.8 & - & - & - & 0 \\
\hline Bacillus & 6.6 & - & - & - & 0 \\
\hline Bacillus & 5.4 & - & - & - & 0 \\
\hline Bacillus & 7.6 & - & 16.8 & - & 1.3 \\
\hline Lysinibacillus & 6.0 & 12.3 & 4.9 & - & 0 \\
\hline Bacillus & 6.7 & - & - & - & 0 \\
\hline Bacillus & 6.6 & - & 19.8 & - & 0 \\
\hline Bacillus & 8.7 & - & 25.9 & - & 18.5 \\
\hline Bacillus & 13.1 & - & 29.5 & - & 0 \\
\hline Bacillus & 7.6 & - & 6.8 & - & 0 \\
\hline Bacillus & 11.0 & - & - & - & 0 \\
\hline Lysinibacillus & 8.6 & - & 28.8 & - & 0 \\
\hline
\end{tabular}

$\operatorname{Trp}=$ trypophan. Activity of C23DO is expressed in $\mu \mathrm{mole} / \mathrm{min} / \mathrm{mg}$ protein 


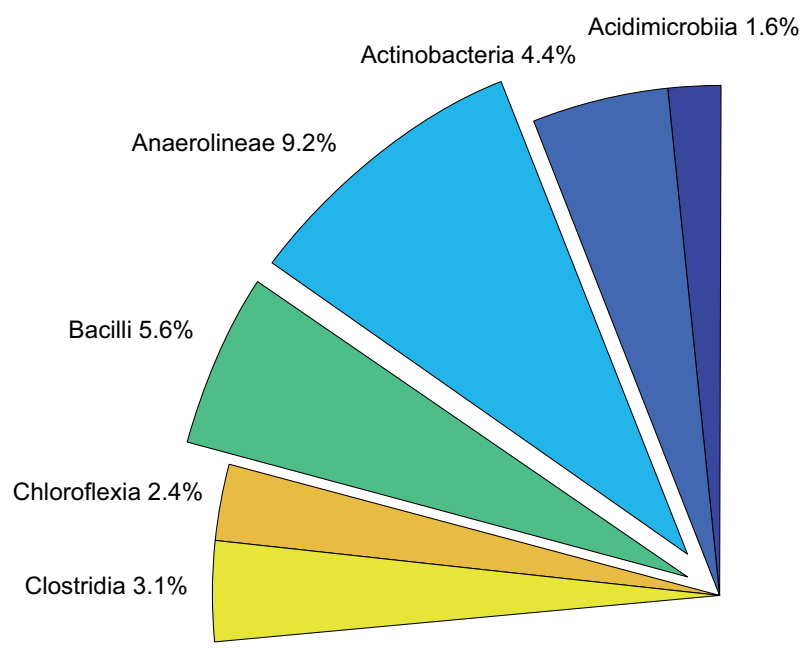

Fig. 5. Relative abundance of bacterial class from metagenomic analysis. Only those classes with more than $1 \%$ of relative abundance are shown. Taken together they represent $26.4 \%$ of the 14730 hits of the total bacterial population. The rest of the classes have less than $1 \%$ of relative abundance or are unknown

(Wang et al. 2018). Also, Anaerolineae, a class of Chloroflexi bacteria has been reported to encode for cellulase and precursors for biofilm (Xia et al. 2016). Thus, the presence of these classes could be explained by the presence of cellulose or hemicellulose present in the initial compost substrate. Moreover, as Xia et al. (2016) have pointed out, the Anaerolineae capability to form biolayers could be helpful to allow other bacteria or consortia to join together on matrices or particles to enhance biodegradation or allowing other bacteria to grow on the substrate surface. Despite that, Xia et al. (2016) observed that Anaerolineae relative abundance could decrease with the time. Contrastingly, Anaerolineae was the most abundant class in compost. Contrastingly, Anaerolineae was the most abundant class in compost. This suggests that the final compost itself could be used as an inoculum for subsequent bagasse composting. Further studies on this sense, beyond the aim of the present work, are required.

Although obtaining an inoculum with the whole consortia would be the most adequate for downstream applications, when using conventional methods, only Bacillus and Lysinibacillus were isolated (Table III). Since some species from Bacillus genus have been described to be resistant to temperature, is not rare to observe them at the end of composting. Bacillus has $3.2 \%$ relative abundance in the compost according to metagenomic analysis and $L y$ sinibacillus were $0.37 \%$ abundant. Keeping that in mind, this suggests that Bacillus are 8.6 times more abundant than Lysinibacillus. Indeed, when isolated in conventional culture media, Bacillus were 14 of the 16 species isolated, whereas Lysinibacillus are the other two. All of the isolates solubilize phosphate, and none of them produced siderophores. In the presence of tryptophan, eight, i.e. $50 \%$ of them were able to produce the phytohormone, indoleacetic acid, whereas, only three isolates would produce the latter in the absence of the aminoacid precursor. Also, three were able to show C23O activity, an enzyme part of the pathway to degrade aromatic compounds, including lignin derivatives. Taken all this together, and since the metagenomic and capacity for promoting plant growth analysis were carried out with the final compost, it suggests that the microbiota would make the compost able to be used as a fertilizer. Moreover, microbiota from Bacilli class would still be able to degrade lignocellulosic residues as described above.

\section{CONCLUSIONS}

It is possible to model the organic matter decay using linear equations at field-scale.

This will allow future prospections at economic level for enterprises and scientists, especially because this work was at the same real-world conditions, when not every parameter can be controlled as in the bench or pilot scale, but as enterprises actually do in Latin America. Temperature and organic matter content at laboratory scale might vary among scales, but our findings suggest that field scale (commercial) parameters seems to be closer to pilot-scale reported by others. It seems that composting depends more on the microbiome and organic matter than in the feedstock per se. The compost produced has bacteria able to promote plant-growth and possibly to enhance degradation of lignocellulose residues.

This research did not receive any specific grant from funding agencies in the public, commercial, or not-for-profit sectors.

\section{REFERENCES}

Arango-Osorno S., Montoya R. J., Vásquez Y. and Flor D.Y. (2016). Physicochemical and microbiological analysis of composting process of leguminous and manure biomass. Rev. Colomb. Cienc. Hort. 10 (2), 345-354. DOI: 10.17584/rcch.2016v10i2.5751 
Bueno-Márquez P., Díaz-Blanco M.J. and CabreraCapitán F. (2008). Factores que afectan el proceso de compostaje. In: Compostaje. (J. Moreno-Casco and R. Moral-Herrero, Eds.) Mundi Prensa, Madrid, Spain, pp. 93-110.

EPA (1998). EPA530-R-98-008. An analysis of composting as an environmental remediation technology. Office of solid waste and emergency response, United States Environmental Protection Agency. Washington, D. C., USA, $115 \mathrm{pp}$.

DOI: 10.1016/S0956-053X(02)00035-1

EPA (1997a) EPA530-F-97-043. Innovative uses of compost, erosion control, turf remediation, and landscaping. Office of solid waste and emergency response, United States Environmental Protection Agency. Washington, D. C., USA, 8 pp.

EPA (1997b) EPA530-F-97-042. Innovative uses of compost, bioremediation and pollution prevention. Office of solid waste and emergency response, United States Environmental Protection Agency. Washington, D. C., USA, 6 pp.

EPA (2006) EPA542/F-06/013. In situ treatment technologies for contaminated soil. Office of solid waste and emergency response, United States Environmental Protection Agency. Washington, D. C., USA, 35 pp.

EPA (2008) EPA542/R-08/002. Green remediation: incorporating sustainable environmental practices into remediation of contaminated sites. Office of solid waste and emergency response, United States Environmental Protection Agency. Washington, D. C., USA, $176 \mathrm{pp}$.

EPA (2016). Types of composting and understanding the process. United States Environmental Protection Agency [online]. http://www.epa.gov/sustainable-management-food/types-composting-and-understandingprocess 12/01/17.

Hupert-Kocurek K., Guzik U. and Wojciszynska D. (2012). Characterization of catechol 2,3-dioxygenase from Planococcus sp. strain S5 induced by high phenol concentration. Acta Bioch. Polon. 59 (3), 345-351.
Ramírez-Sandoval M. and Velázquez-Fernández J.B. (2013). Organ-dependent GST activation in Ocimum basilicum by endosulfan exposure. Química hoy, Chemistry Sciences 3 (1), 38-40.

Rodríguez R., Jiménez J.F., Real J.I., Salcedo E., Zamora J.F. and Íñiguez G. (2013). Utilization of byproducts of tequila industry. Composting raw agave bagasse and biosolids from a treatment plant of tequila vinasses. Rev. Int. Contam. Ambie. 29 (4), 303-313.

Roncevic S., Dalmacija B., Ivancev-Tumas I., Trickovic J., Petrovic O., Klasnja M. and J. Agbaba. (2005). Kinetics of degradation of hydrocarbons in the contaminated soil layer. Arch. Environ. Contam. Toxicol. 49 (1), 27-36. DOI: 10.1007/s00244-004-0048-6

SEMARNAT (2000). NOM-021-RECNAT-2000. Norma oficial mexicana que establece las especificicaciones de fertilidad, salinidad y clasificación de suelos. Estudios, muestreo y análisis. Secretaría de medio ambiente y recursos naturales. Diario Oficial de la Federación. Mexico City, Mexico, 73 pp.

Xia Y., Wang Y., Wang Y., Chin F.Y.L. and Zhang T. (2016). Cellular adhesiveness and cellulolytic capacity in Anaerolineae revealed by omics-based genome interpretation. Biotechnol. for Biofuels. 9, 111.

DOI: $10.1186 / \mathrm{s} 13068-016-0524-\mathrm{z}$

Xu P. and J. Li. (2017). Effects of microbial inoculant on physical and chemical properties in pig manure composting. Compost Sci. Util. 25 (Sup1), S37-S42. DOI: 10.1080/1065657X.2017.1295886

Wang X.C., You S.P., Zhang J.X., Dai Y.M., Zhang C.Y., Qi W., Dou T.Y., Su R.X. and He Z.M. (2018). Rational design of a thermophilic $\beta$-mannanase from Bacillus subtilis TJ-102 to improve its thermostability. Enzyme Microb. Tech. 118, 50-56.

DOI: $10.1016 /$ j.enzmictec.2018.07.005 